\section{Barns tilpasning til traumer}

Zeuthen $\mathrm{K}$.

Kærlighed og overlevelse

Barneseksualitet og seksuelle traumer. 237 s. København: Akademisk Forlag, 2009.

Pris DKK 269

ISBN 978-87-500-4094-1

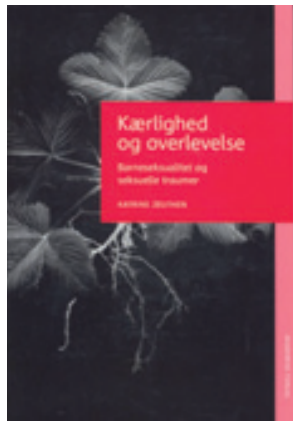

Dette er en omarbeidet versjon av psykolog Katrine Zeuthens ph.d.grad med samme tittel fra 2007. Hun utførte dette arbeidet mens hun var tilknyttet «Team for seksuelt misbrukte børn» ved Rigshospitalet i København. Zeuthen ønsker å nå voksne som er opptatt av og har omsorg for barn der det er mistanke om seksuelt misbruk. Hensikten er å øke forståelsen for barnets tilpasning til både det å ha blitt utsatt for overgrep og til de voksne som tar vare på barnet. Sentralt for forfatteren blir argumentasjonen for at barnet alltid fungerer i en relasjon, barnet er alltid avhengig av en voksen og barnets tilpasning til traumet vil alltid preges av dette. Barnets utvikling og relasjoner til andre blir forstyrret ved overgrep fra voksne.

Språket er et stort sett lettforståelig dansk. Forfatteren tar utgangspunkt i psykoanalytisk orientert tenkning - med vekt på både ubevisst og bevisst tilpasning. Dette gir styrke til beskrivelsene, men kan også gjøre deler av teksten vanskelig tilgjengelig for lesere som ikke er spesielt inne i psykoanalytiske begreper og teorier.

Katrine Zeuthen gir først en generell innføring i temaet «barn utsatt for seksuelle overgrep», med utgangspunkt i danske erfaringer og undersøkelser. Disse synes å være i overensstemmelse med både norsk (1) og internasjonal kunnskap. Hun går så raskt videre til hovedprosjektet: $\AA$ beskrive barnets subjektive opplevelse og relasjonelle tilpasning. Tre kasus illustrerer tenkningen gjennom alle kapitler, samtidig beskrives disse kasusene mer detaljert gjennom egne kapitler senere. Etter innledningskapitlet begrunnes barnets tilpasning til det å ha blitt utsatt for overgrep og omsorgssvikt. Her legges det vekt på barnet og tilpasningen til andre - med gjennomgang av psykoanalytisk utviklingspsykologi og mer moderne tilknytnings- og mentaliseringsteori. Som innledning til de tre omfattende kasuspresentasjonene diskuteres formålet med psykoanalytisk orientert behandling: $\AA$ hjelpe barnet tilbake til egen utvikling. Siste kapittel er en diskusjon av psykoanalysens bidrag til vår viten og vitenskapen om barns opplevelser av traumer; opplevelser som også er forskjellig fra det observerte som ofte beskrives som kognitive, fenomenologiske og nevrovitenskapelige fenomener. Den psykoanalytiske forståelsen blir da et supplement til å forstå barnets motivasjoner.

Styrken er de detaljerte innblikk Koerlighed og overlevelse gir i behandlingen av traumatiserte barn. Kasuspresentasjonene er en beskrivelse av formålet med behandlingen, både metode og tenkning underbygger argumentasjonen for hvorfor det må jobbes med barnets relasjoner gjennom relasjonen til terapeuten. Kasuspresentasjonene er også et sterkt bidrag til å åpne opp for innsyn i hva som skjer i psykoterapi med barn og dermed også i psykoanalytisk orientert behandling generelt. Boken er egnet for kolleger og andre som er opptatt av hvordan barnet subjektivt og relasjonelt opplever og tilpasser seg traumer, et perspektiv som sjelden kommer frem i slik systematisert form.

\section{Rune Johansen}

Oslo

\section{Litteratur}

1. Myhre AK, Borgen G, Ormstad K. Seksuelle overgrep mot prepubertale barn.

Tidsskr Nor Lægeforen 2006; 126: 2511-4.

\section{EKG-samling med for kortfattede kommentarer}

Pahlm 0 .

\section{EKG i klinisk praxis}

Fallbeskrivningar med tolkningar. 209 s, tab, ill. Lund: Studentlitteratur, 2008. Pris SEK 280 ISBN 978-91-44-05171-0

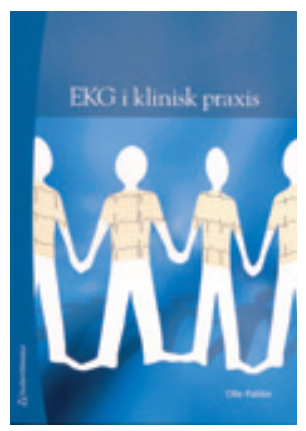

Studenter og turnusleger opplever ofte at EKG-tolking er vanskelig. Overgangen virker stor fra de fysiologiske prinsippene til klinikerens handlingskompetanse. Derfor er erfarne klinikeres gode eksempel-

samlinger med tolkinger nyttige både for forståelse og gjenkjennelse. Olle Pahlm, professor i klinisk fysiologi og overlege ved Bild- och Funktionsdiagnostiskt Centrum ved Lunds universitet har utgitt en samling med 100 EKG-er. Forfatteren er en velrenommert forsker på feltet og har deltatt i den amerikanske komiteen som har utarbeidet retningslinjer for tolking av EKG.

EKG-ene er lekkert reprodusert. Man har valgt å fremstille ett gjenomsnitts QRSkompleks for hver avledning og en rytmeremse over noen sekunder fra avledning II. Dette gir glatte, pene og støyfrie signaler, men passer dårlig når ikke alle hjerte- slagene er like. Heldigvis har forlaget lagt ut de komplette registreringene på Internett.

Tolkingene er svært knappe, og premissene for dem oppgis sjelden. Det reduserer nytteverdien, fordi den mindre erfarne leser ofte vil måtte slå opp i en lærebok for å finne for eksempel grenseverdiene for venstre ventrikkel-hypertrofi og hvordan man frekvenskorrigerer QT-tiden. Utvalget er bra med hensyn til akutt hjerteinfarkt, selv om det fokuseres lite på STEMI (ST-elevasjonsinfarkt) og nSTEMI, der skillet er viktig for å avgjøre når det skal utføres kononarintervensjon. Dessuten savner jeg perikarditt, elektrolyttforstyrrelser og EKG hos barn, og jeg skulle ønske at forfatteren hadde brukt Cornells kriterier for å vise venstre ventrikkel-hypertrofien i eksemplene 52 og 77 . Disse kjennetegnene er viktige for oppfølgingen av hypertonipasienter. Det hadde også vært nyttig å sett noen eksempler der computertolking av EKG er bra eller dårlig. Emnemessig er EKG-ene i tilfeldig rekkefølge. Dette avspeiler den kliniske hverdagen, men gjør boken mindre egnet for oppslag.

Blant kardiologer går det sport i å være uenig om tolkingen av EKG. Jeg finner således en drøy håndfull eksempler der jeg er uenig med tolkingen eller synes den er mangelfull. Den største innvendingen min er likevel de altfor knappe kommentarene med diagnostiske premisser og kliniske konsekvenser. Dette burde kunne rettes opp i senere opplag.

\section{Knut Gjesdal}

Hjertemedisinsk avdeling

Oslo universitetssykehus, Ullevål

\section{Nytt, men utdatert operasjonsatlas}

\section{Schumpelick V.}

Atlas of general surgery

608 s, ill. Stuttgart: Thieme, 2009. Pris EUR 130 ISBN 978-3-13-144091-4

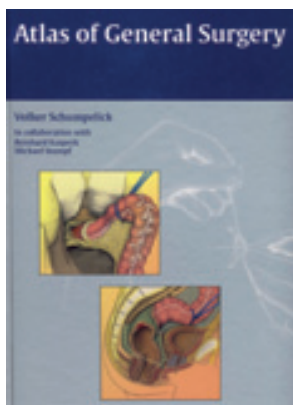

Tre år etter den andre tyske utgaven av dette operasjonsatlaset foreligger det nå $i$ engelsk oversettelse. Det er tenkt som et oppslagsverk for utdanningskandidater i kirurgi, og skal dekke det forfat-

teren mener enhver kirurg bør beherske, uavhengig av grenspesialitet.

En generell innledende del tar for seg grunnleggende kirurgisk teknikk og enkle prosedyrer som urinblærekateterisering, pleurapunksjon, ascitespunksjon og venøse 
tilganger. Hoveddelen omfatter 150 større og mindre inngrep og prosedyrer ordnet etter organsystem: hud og bløtvev, hals, thorax, abdomen, retroperitoneum og ytre genitalia. Emner som brokk, barnekirurgi, karkirurgi og amputasjoner er også dekket. Kapitlet om traumatologi er rent ortopedisk rettet og inkluderer håndtering av septisk gonartritt og operasjon ved Dupuytrens kontraktur og karpaltunnelsyndrom.

Utvalget av prosedyrer virker litt vilkårlig, og spennet er stort, fra incisjon av paronyki til anatomisk lungereseksjon, leverreseksjon og rectumreseksjon. De sistnevnte står ikke på utdanningsrepertoaret til dagens norske kandidater innen generell kirurgi. Enkelte inngrep, for eksempel selektiv proksimal eller trunkal vagotomi og Bassinis plastikk ved lyskebrokk er nå lite aktuelle. Utvalget av torako-laparoskopiske prosedyrer er meget begrenset. Kirurgi ved tykktarmskreft eller ventralhernier er for eksempel kun beskrevet med åpen tilgang.

Hvert inngrep er beskrevet trinnvis i ti punkter: indikasjon, preoperative forberedelser, pasientinformasjon, anestesi, leiring, tilgang, operasjonsteknikk, anatomi, håndtering av spesielle komplikasjoner og postoperativ behandling. Den skjematiske fremstillingen er oversiktlig, men medfører også oppramsing av en del selvfølgeligheter.

Den anbefalte litteraturen er rundt 20 år gammel, og dette gjenspeiles i teksten.

Ved hemikolektomi anbefales preoperativ tarmtømming, postoperativ nasogastrisk sonde og abdominaldren $\mathrm{i}$ henholdsvis 1-3 og 7-8 dager. Små slurker klar væske tillates fra 3.-4. dag, fast føde etter første avføring, rundt 7. dag. Eksemplet illustrerer hvor vanskelig det er å innføre moderne prinsipper for perioperativ behandling. Tarmanastomoser anlegges med avbrutte fullveggssuturer. Trådvalget omfatter kromcatgut og silke. Ved «gastric outlet obstruction» nevnes ikke endoskopisk stent-behandling som et alternativ, og intervensjonsradiologi er ikke nevnt som en mulighet ved blødende peptisk ulcus.

Dette er et verk i stort format, solid innbundet og på godt papir. De 1223 illustrasjonene er i svart-hvitt og av varierende kvalitet. Enkelte komplekse prosedyrer, som lungereseksjoner, illustreres så knapt og overfladisk at det ikke er til hjelp. Andre inngrep, for eksempel ved lyskebrokk, er bedre beskrevet.

Forfatteren, professor Schumpelick, er sjef for kirurgisk avdeling ved universitetssykehuset i Aachen, president i den tyske kirurgiske forening, lærebokforfatter og en nestor i tysk kirurgi. Atlas of general surgery er utgitt på Thieme, et kvalitetsforlag for medisinsk litteratur. Resultatet er skuffende.

\section{Introduksjon til stråleterapi}

Degerfält J, Moegelin I-M, Sharp L. Strålbehandling

276 s, tab, ill. Lund: Studentlitteratur, 2009 Pris SEK 331

ISBN 978-91-44-04523-8

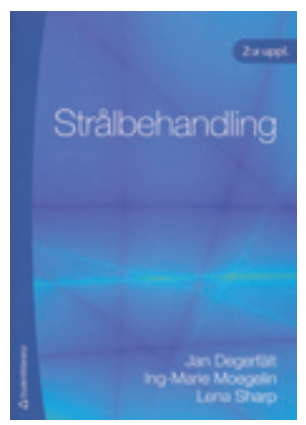

Onkologi som selvstendig spesialitet (terapeutisk onkologi og stråleterapi) ble opprettet i 1964. Spesialiteten sprang ut fra diagnostisk radiologi, der man inntil da hadde tatt hånd om stråleterapi av benigne

så vel som maligne lidelser. Behovet for en egen spesialitet meldte seg etter hvert som det medikamentelle tilbud til kreftpasienter økte. Spesialiteten skiftet navn til onkologi i 1991 og omfatter både stråleterapi og medikamentell behandling av kreft. I en del andre land er dette separate spesialiteter.

Utviklingen innen medisinsk bildediagnostikk de siste tiår har vært enorm. Dette, sammen med utviklingen av datateknologien, har spesielt kommet kreftbehandlingen til gode ved at presisjonsnivået for stråleterapi har økt betraktelig. Stråling avleveres nå med millimeters nøyaktighet i forhold til målvolumet.

Stråleterapi er en tverrfaglig aktivitet som fordrer tett samarbeid mellom sykepleiere, stråleterapeuter, fysikere, radiologer og onkologer. Førsteforfatteren er stråleterapeut og adjunkt ved Lunds universitet, avdelingen for onkologi. De to andre forfattere er sykepleiere med årelang klinisk og pedagogisk erfaring innen kreftomsorg.

Dette er en kortfattet lærebok i stråleterapi. Språket er svensk, formatet hendig og innbindingen robust (paperback) utmerket egnet til å slå opp i for sykepleiere på post. Illustrasjonene er enkle og tjener som et godt supplement til teksten. Bakerst er det illustrerende fotografier.

Den er tredelt: I kapittel 1-7 tar man for seg fysiske og tekniske aspekter vedrørende stråleterapi, i kapittel 8 er det strålebiologi og i kapittel 9-18 pleiemessige forhold under og etter stråleterapi. Jeg synes forfatterne har fătt med seg det viktigste rundt stråleterapiprosessen, om enn meget kortfattet. Noen begreper blir hengende i luften, men det er rikelig med relevante referanser. Dette er 2. utgave, jeg synes faktisk 1. utgave var mer utfyllende på dette området. Strålebiologien er greit ivaretatt, særlig fraksjonering. I siste del omhandles psykososiale forhold og bivirkninger ved strålebehandling og håndtering av dette. Her finnes mye nyttig informasjon til bruk i den kliniske hverdag, og det er rikelig med henvisninger til oppdatert relevant litteratur.
Samlet sett er dette en god introduksjon til stråleterapi, godt egnet for sykepleiere som tar hånd om pasientene under og etter behandlingen. Den passer også utmerket for medisinstudenter som vil sette seg inn i stråleterapien, et fag jeg for øvrig har inntrykk av har for liten plass i det medisinske studium. Stråleterapeuter vil særlig ha nytte av siste tredel. For fysikere og onkologer er imidlertid Strålbehandling til relativt liten nytte, den er for elementær til det.

\section{Jan Folkvard Evensen}

Kreftklinikken

Oslo universitetssykehus, Rikshospitalet

\section{Hjemmetjenestene - små fakta om store problemer}

\author{
Verdens helseorganisasjon \\ Home care in Europe \\ 36 s, tab, ill. København: WHO, 2008. \\ Pris CHF 10
}

ISBN 978-92-890-4281-9

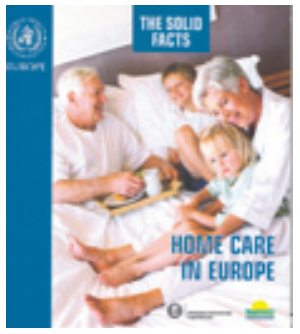

«Overtittelen»på denne lille utgivelsen om hjemmetjenester i Europa er «The solid facts». Den er utgitt av Europakontoret til Verdens helseorganisasjon og Bocconi

University i Milano. Det er mange bidragsytere fra flere europeiske land, men ingen fra de nordiske landene.

Man starter med å slå fast at behovet for hjemmetjenester øker i alle land pga. eldrebølgen og fordi det blir flere mennesker med kroniske sykdommer. Det er fire kapitler: oversikt over hjemmetjenestene i Europa, de økende behovene, tilbudssiden og utfordringene for politikk og administrasjon. Teksten er grei nok, det er eksempler fra mange av landene (i små rammer med liten skrift) og noen få, delvis uleselige figurer.

Forfatterne drøfter de økende utfordringene: stadig større behov, for lite ressurser, dårlig samarbeid mellom spesialisthelsetjenesten og hjemmetjenestene (noe som fører til svingdørspasienter ved sykehusene og forsømte pasienter i hjemmene) og dårlig kommunikasjon. I alle land forsøker man å mobilisere til mer innsats fra de pårørende og å utvikle alle slags «lure løsninger» for fordeling av ansvar og kostnader. Jeg leser alt dette med et sukk - dels fordi så mange pårørende enten er døde eller har flyttet, dels fordi det ikke finnes hemmelige triks. Man kan tro på konkurranseutsetting og «co-payment» og overlate ansvaret til den enkelte, eller man kan tro på full dekning fra det offentlige. Men problemene er hele 